\title{
ANALISIS PELAKSANAAN PROGRAM PPK MELALUI KEGIATAN TADARUS DALAM MENGEMBANGKAN NILAI RELIGIUS
}

\author{
Fitri Damayanti ${ }^{1}$, Eka Sari Setianingsih ${ }^{2}$, Husni Wakhyudin ${ }^{3}$ \\ 1,2,3 Jurusan Pendidikan Guru Sekolah Dasar, FIP \\ Universitas PGRI Semarang \\ email : fitridamayanti11@gmail.com¹,EkaSari123@gmail.com². \\ Husni456@gmail.com ${ }^{3}$
}

\begin{abstract}
Abstrak
Tujuan yang hendak dicapai dalam penelitian ini adalah adalah untuk mengetahui hasil analisis pelaksanaan program PPK melalui kegiatan tadarus di SD Negeri Pamongan 02 Guntur. Jenis penelitian ini adalah deskriptif kualitatif. Sampel yang diambil adalah 40 siswa kelas III dan IV SD Negeri Pamongan 02 Guntur diolah dengan secara trianggulasi data. Data dalam penelitian diperoleh melalui observasi, wawancara, dokumentasi, dan angket. Hasil dalam penelitian ini menunjukkan bahwa pelaksanaan program pendidikan karakter dilakukan melalui kegiatan berdoa sebelum pembelajaran di mulai, membaca Al-Qur'an, sholat dhuhur berjamaah bersama, sholat dhuha ketika pembelajaran Agama, dan pesantren kilat yang diadakan setiap satu tahun sekali pada bulan ramadhan. Nilai religius siswa kelas III dan kelas IV SD Negeri Pamongan 02 Guntur sudah berjalan dengan baik, hal ini dibuktikan dengan adanya hasil observasi, wawancara, dan angket. Hasil angket karakter religius menunjukkan hasil yang sangat tinggi dengan rata-rata kriteria sangat religius.
\end{abstract}

Kata kunci: PPK, Tadarus, Nilai Religius

\section{Abstract}

The objective to be achieved in this research was to find out the results of the analysis of the KDP program implementation through tadarus activities in Pamongan 02 Guntur Elementary School. This type of research is qualitative descriptive. The sample taken was 40 students of class III and IV of SD Negeri Pamongan 02 Guntur processed by triangulation of data. Data in the study were obtained through observation, interviews, documentation, and questionnaires. The results in this study indicate that the implementation of character education programs carried out through prayer activities before learning begins, reading the Qur'an, dhuhur prayers together in congregation, praying in the religious learning religion, and lightning pesantren held once a year during the month of Ramadan. The religious grades of third and fourth grade students at Pamongan 02 Guntur Elementary School have gone well, this is evidenced by the results of observations, interviews, and questionnaires. The results of the religious character questionnaire showed very high results with very religious criteria.

Keywords: KDP, Tadarus, Religious Value 


\section{Pendahuluan}

Pendidikan merupakan kegiatan yang kompleks, dan meliputi berbagai komponen yang berkaitan erat satu sama lain. Oleh sebab itu, apabila pendidikan ingin dilaksanakan secara terencana dan teratur, maka berbagai faktor yang terlibat dalam pendidikan harus dipahami terlebih dahulu. Berbagai komponen dalam sistem pendidikan, baik secara mikro maupun dalam kajian makro perlu dikenali secara mendalam sehingga komponen-komponen tersebut dapat difungsikan dan dikembangkan guna mengoptimalkan garapan pendidikan tersebut ke arah pencapaian tujuan pendidikan yang ditetapkan (Dinn Wahyudi dkk, 2006) (Sutrisno, 2016).

Pendidikan lebih dari sekedar pengajaran, yang dapat dikatakan sebagai suatu proses transfer ilmu, transformasi nilai, dan pembentukan kepribadian dengan segala aspek yang dicakupnya. Dengan demikian pengajaran lebih berorientasi pada pembentukan spesialis atau bidangbidang tertentu, oleh karena itu perhatian dan minatnya lebih bersifat teknis. Pendidikan merupakan suatu proses yang diperlukan untuk mendapatkan keseimbangan dan kesempurnaan dalam perkembangan individu maupun masyarakat. Penekanan pendidikan dibanding dengan pengajaran terletak pada pembentukan kesadaran dan kepribadian individu atau masyarakat di samping transfer ilmu dan keahlian. Dengan proses semacam ini suatu bangsa atau negara dapat mewariskan nilai-nilai keagamaan, kebudayaan, pemikiran dan keahlian kepada generasi berikutnya, sehingga mereka betul-betul siap menyongsong masa depan kehidupan bangsa dan negara yang lebih cerah. Pendidikan juga merupakan sebuah aktifitas yang memiliki maksud atau tujuan tertentu yang diarahkan untuk mengembangkan potensi yang dimiliki manusia baik sebagai manusia ataupun sebagai masyarakat dengan sepenuhnya (Nurkholis, 2013).

Pasal 1 UU SISDIKNAS no. 20 tahun 2003 disebutkan bahwa Sistem Pendidikan Nasional adalah keseluruhan komponen pendidikan yang saling terkait secara terpadu untuk mencapai tujuan pendidikan nasional. Berangkat dari bunyi pasal ini dapat diketahui bahwa pendidikan adalah sistem yang merupakan suatu totalitas struktur yang terdiri dari komponen yang saling terkait dan secara bersama menuju kepada tercapainya tujuan (Soetarno, 2003: 2). Adapun komponen-komponen dalam pendidikan nasional antara lain adalah lingkungan, sarana-prasarana, sumberdaya, dan masyarakat. Komponen-komponen tersebut bekerja secara bersama-sama, saling terkait dan mendukung dalam mencapai tujuan pendidikan (Munirah, 2015).

Pemerintah memberi jawaban mengenai perkembangan zaman yang semakin mengancam nilai moral dan karakter anak-anak Indonesia melalui kurikulum 2013 dengan mengembangkan penguatan pendidikan karakter pada anak. Hal ini sejalan dengan tujuan pendidikan karakter sesuai peraturan presiden (perpres) No.87 Tahun 2017 tentang penguatan pendidikan karakter yang berbunyi "PPK dilaksanakan dengan menerapkan nilai-nilai Pancasila dalam pendidikan karakter terutama meliputi nilai-nilai religius, jujur, toleran, disiplin, bekerja keras, kreatif, mandiri, demokratis, rasa ingin tahu, semangat kebangsaan, cinta tanah air, menghargai prestasi, komunikatif, cinta damai, gemar membaca, peduli lingkungan, peduli sosial, dan bertanggungiawab.

Pemerintah memberi jawaban mengenai perkembangan zaman yang semakin mengancam nilai moral dan karakter anak-anak Indonesia melalui kurikulum 2013 dengan mengembangkan penguatan pendidikan karakter pada anak. Hal ini sejalan dengan tujuan pendidikan karakter sesuai peraturan presiden (perpres) No.87 Tahun 2017 tentang penguatan pendidikan karakter yang berbunyi "PPK dilaksanakan dengan menerapkan nilai-nilai Pancasila dalam pendidikan karakter terutama meliputi nilai-nilai religius, jujur, toleran, disiplin, bekerja keras, kreatif, mandiri, demokratis, rasa ingin tahu, semangat kebangsaan, cinta tanah air, menghargai prestasi, komunikatif, cinta damai, gemar membaca, peduli lingkungan, peduli sosial, dan bertanggungiawab.

Dilansir dari media massa online kompasiana.com https://www.kompasiana.com/biyanka/5742766d949773c304e0b781/degradasi-moral-bangsa- 
indonesia, diakses pada tanggal 21 Oktober 2018). Pada artikel tersebut menyatakan bahwa Bangsa Indonesia mengalami degradasi moral. Hal itu ditandai dengan adanya budaya hedonisme yang tinggi, pola berpakaian yang mini dan menurunnya sikap sopan santun terhadap orang lain.

Beranjak dari permasalahan yang muncul di Indonesia, maka peneliti melakukan observasi di SD Negeri Pamongan 02 Guntur. Hasil observasi di SD Negeri Pamongan 02 Guntur sudah menerapkan gerakan PPK. Gerakan PPK tersebut dapat dilihat dari ada nya program tadarus, yaitu melakukan kegiatan tadarus setiap pagi di sekolah. Selain itu, masih terdapat beberapa dinamika implementasi dalam penanaman nilai-nilai karakter yang perlu digali lebih dalam oleh peneliti.

Hasbullah (2017:227) mengartikan pendidikan sebagai usaha yang dijalankan seseorang dan kelompok orang lain agar menjadi orang dewasa untuk mencapai tingkat kehidupan yang lebih tinggi dalam arti mental. Sedangkan pengertian pendidikan yang dijelaskan oleh Soegeng (2018:226) mengartikan pendidikan sebagai proses manusiawi yang terwujud dalam proses pendewasaan, pembentukan diri sendiri, menuju kedewasaan yang susila serta melalui internalisasi (pembatinan) nilai-nilai kemanusiaan.

Daryanto (2013:47) mengemukakan 18 nilai yang bersumber dari agama, pancasila, budaya, dan tujuan pendidikan nasioanal, yaitu: (1) Religius, (2) Jujur, (3) Toleransi, (4) Disiplin, (5) Kerja keras, (6) Kreatif, (7) Mandiri, (8) Demokratis, (9) Rasa ingi tahu, (10) Semangat kebangsaan, (11)Cinta tanah air, (12) Menghargai prestasi, (13) Bersahabar/komunikatif, (14) Cinta damai, (15) Gemar membaca, (16) Peduli lingkungan, (17) Peduli sosian dan (18) Tanggung jawab.

Menurut Zamroni dalam Syamsul Kurniawan (2017:124) menyatakan bahwa budaya sekolah adalah suatu pola asumsi-asumsi dasar, nilai-nilai, keyakinan-keyakinan, dan kebiasaan-kebiasaan yang dipegang bersama oleh seluruh warga sekolah yang diyakini dan dapat di pergunakan untuk menghadapi berbagai masalah dalam beradaptasi dengan lingkungannya yang baru, sehingga pola nilai dan asumsi tersebt dapat diajarkan kepada anggota dan generasi baru agar mereka memiliki pandangan yang tepat untuk memahami berpikir, merasakan dan bertindak untuk menghadapi berbagai situasi dan lingkungan yang ada.

Menurut Kisyani laksono suatu budaya sekolah yang kondusif akan membabawa manfaat: Pertama, secara produktif mampu memberikan bagi bertumbuhkembangnya: 1) keimanan dan ketakwaan peserta didik terhadap Tuhan Yang Maha Esa; 2) kesahajaan dan nasionalisme peserta didik; 3) semangat kebersamaan, persatuan, dan kerja kelompok peserta didik; 4) semangat membaca dan mencari referensi; 5) keterampiian peserta didik dalam mengkritisi data dan memecahkan masalah hidup; 6) kecerdasan emosional peserta didik; 7) keterampilan komunikasi peserta didik, baik secara lisan maupun tertulis; 8) kemampuan peserta didik untuk berpikir objektif dan sistematis; 9) kecakapan peserta didik dalam bidang tertentu yang terdapat di masyarakat. Kedua, budaya sekolah yang kondusif, akan tampak atau tecermin dalam struktur organisasi sekolah, deskripsi tugas sekolah, sistem dan prosedur kerja sekolah, pegawai, kebijakan dan aturan, tata tertib sekolah, kepemimpinan dan hubungan, acara atau ritual, dan penampilan fisik sekolah yang juga tumbuh dan berkembang (Mustari, 2013).

Sedangkan Deal dan Peterson dalam Daryanto (2013:17) menyatakan budaya sekolah adalah sekolah yang mempunyai budaya tersendiri yang berupa serangkaian nilai, norma, aturan moral, dan kebiasaan yang telah berlaku di lingkungan sekolah.

Yaumi (2014:85) berpendapat bahwa nilai religius adalah salah satu nilai karakter yang dijadikan sebagai sikap dan perilaku yang patuh dalam melaksanakan ajaran agama yang di anut, toleran terhadap pelaksanaan ibadah agama lain, dan hidup rukun dengan pemeluk agama lain. Dan juga religius bisa dikatakan sebagai tradisi, sebuah sitem yang mengatur tata keimanan dan peribadatan terhadap Tuhan Yang Maha Esa serta tata kaidah yang berhubungan dengan pergaulan manusia serta lingkungannya.

Perkembangan lembaga pendidikan AI-Qur'an yang semakin pesat saat ini menandakan makin meningkatnya kesadaran masyarakat akan pentingnya kemampuan baca tulis Al-Qur'an 
dan keberadaannya ditengahtengah masyarakat. Keberadaan pendidikan Al-Qur'an membawa misi yang sangat mendasar terkait dengan pentingnya memperkenalkan dan menanamkan nilai-nilai Al-Qur'an sejak usia dini (Tim Dirjen Pendis Depag RI, 2009). Pada saat ini, lembaga pendidikan AI-Qur'an berupa TPQ atau sejenisnya telah cukup eksis. Dengan disahkannya PP.No. 55 Tahun 2007 tentang pendidikan Agama dan Pendidikan Keagamaan, makin memperkokoh lembaga pendidikan Al-Qur'an, sehingga menuntut penyelenggaraannya untuk lebih professional. Keberadaan Lembaga Pendidikan Al-Qur'an tidak dapat dilepaskan dari peran serta pemerintah, masyarakat dan organisasi-organisasi masa Islam. Latar dari penelitian ini adalah pemberdayaan masyarakat pesisir melalui peningkatan kapasitas pendidikan keagamaan pada masyarakat pantai Kelurahan Talia. Pemberdayaan keagaaman yang dimaksudkan adalah pelaksanaan kegiatan baca tulis al-Qur'an yang demikian menjadi dasar pengajaran agama Islam (Aliwar, 2016).

Al-Qur'an memang bukan sebuah kitab ilmu pengetahuan melainkan sebuah kitab petunjuk bagi ummat manusia, akan tetapi didalamnya banyak kita temukan ayat yang memberikan isyarat tentang kebenaran ilmu pengetahuan. Al-Qur'an adalah wahyu Allah yang disampaikan kepada rasulNya Muhammad saw. 15 abad tahun yang lalu. Al-Qur'an telah memberikan isyarat dan dorongan kepada umat manusia agar menuntut dan mengembangkan ilmu pengetahuan. Diantaranya wahyu Al-Qur'an atau ayat pertama kali turun kepada Nabi Muhammad saw (ling, 2014).

Adanya pembudayaan tadarus di sekolah dapat meningkatkan nilai karakter religius siswa. Hal itu sesuai dengan ajaran Allah SWT dalam Islam yang menganjurkan setiap umatNya untuk mambaca Al- Qur`an. Sejalan dengan Syarbini dan Jamhari (2012:49) menjelaskan Tadarus merupakan sebuah ibadah dan mendapatkan pahala. Pada kegiatan tadarus kita disuruh untuk meneladani karakter-karakter (akhlak) Allah SWT. Al- Qur'an mempunyai pengaruh yang sangat kuat terhadap jiwa manusia. Demikian pula terhadap jiwa anak-anak. Semakin jernih jiwa anak, maka semakin bertambah pula kecerdasan spiritualnya. Pembiasaan kegiatan tadarus berpengaruh terhadap sikap-sikap positif karena ketika membaca Al- Qur`an diibaratkan berkomunikasi langsung dengan Allah Sang Maha Pencipta.

Penelitian yang ditulis oleh Dian Chrisna Wati dengan judul "Penanaman Nilai-nilai Religius di Sekolah Dasar untuk Penguatan Jiwa Profetik Siswa" yang termuat dalam jurnal Universitas Ahmad Dahlan, Yogyakarta pada November 2017. Penelitian ini menunjukkan bahwa nilai-nilai religius yang ditanamkan di SD Muhammadiyah Sidoarum meliputi nilai disiplin, kejujuran, tanggung jawab, ikhlas, toleransi, saling menghargai, dan peduli lingkungan. Penanaman nilai religius terintegrasi dalam semua mata pelajaran, budaya sekolah, dan kegiatan ekstrakurikuler. Penelitian juga menunjukkan adanya faktor-faktor internal dan eksternal yang menghambat penanaman nilai-nilai religius untuk penguatan jiwa profetik siswa.

Tujuan dalam penelitian ini yaitu untuk mengetahui hasil analisis pelaksanaan program PPK melalui kegiatan tadarus dalam mengembangkan nilai religius siswa SD Negeri Pamongan 02 Guntur.

\section{Metode}

Penelitian ini menggunakan pendekatan kualitatif, yaitu penelitian yang berupa deskripsif. Penelitian kualitatif adalah metode yang digunakan untuk memahami fenomena yang sedang terjadi pada kondisi yang alamiah. Penelitian ini telah dilaksanakan di Sekolah Dasar Negeri Pamongan 02 Kecamatan Guntur pada semester genap Tahun Pelajaran 2018/2019 pada tanggal 13 Mei - 18 Mei 2019. Untuk subjek pada penelitian ini adalah Kepala Sekolah, guru kelas III. Guru kelas IV, guru PAI, siswa kelas III yang berjumlah 20 siswa, dan siswa kelas IV yang berjumlah 20 siswa.

Sumber data kualitatif dalam penelitian ini data yang berupa fakta-fakta yang diperoleh dari observasi, wawancara, dokumentasi, dan angket pelaksanaan program PPK melalui kegitan tadarus dalam mengembangakan nilai religius siswa SD Negeri Pamongan 02 Guntur. Teknik pengumpulan data adalah lagkah utama dalam suatu penelitian dengan tujuan dalam penelitian adalah mendapatkan data. Pengumpulan data dilakukan dalam berbagai setting, 
berbagai sumber, dan berbagai cara. Jika dilihat dari settingnya, data dikumpulkan pada setting alamiah seperti dirumah, diskusi, di jalan dengan berbagai responden. Bila dilihat dari sumber datanya, maka pengumpulan data dapat menggunakan sumber primer dan sumber sekunder. Sumber primer adalah sumber data yang langsung memberikan data kepada pengumpul data, dan sumber data sekunder merupakan sumber data yang tidak langsung memberikan data kepada pengumpul data, misalnya lewat orang lain atau lewat dokumen. Selanjutnya bila dilihat dari segi cara atau teknik pengumpulan data, maka teknik pengumpulan data dapat dilakukan dengan observasi (pengamatan), interview (wawancara), dokumentasi, dan angket.

Dilihat dari settingnya, data dalam penelitian ini dikumpulkan pada setting alamiah di sekolah di SD Negeri Pamongan 02 Guntur dengan berbagai responden. Peneliti terjun secara langsung ke sekolah untuk melakukan penelitian dengan cara observasi, wawancara, dokumentasi, dan angket terhadap responden, yaitu: kepala sekolah, guru, dan siswa. Hal ini menunjukkan bahwa penelitian yang dilakukan menggunakan pengumpulan sumber data primer dan sumber sekunder.

Sumber primer dalam penelitian ini adalah kepala sekolah, guru, dan siswa yang memberikan data kepada peneliti. Sedangkan sumber sekunder dalam penelitian ini adalah dokumentasi tentang pelaksanaan program PPK melalui kegiatan tadarus dalam mengembangkan nilai religius siswa SD Negeri Pamongan 02 Guntur.

Untuk memperoleh data yang diperlukan dan sesuai dengan pembahasan dalam pene litian, maka peneliti menggunakan instrumen berupa observasi, wawancara, dan dokumentasi. Berikut penjelasannya:

\section{Observasi}

Dalam penelitian ini, observasi bertujuan untuk mengetahui budaya atau kebiasaan di sekolah, sehingga peneliti akan mengetahui lebih jauh mengenai bagaimana pelaksanaan program PPK melalui kegiatan tadarus disekolah. Observasi dilakukan untuk mencari data nilai religius siswa pada proses kegiatan dengan mengamati siswa serta guru dalam pelaksanaan program PPK melalui kegiatan tadarus pada siswa. Dalam mengobservasi, peneliti mengguanakan lembar observasi untuk mengamati karakter siswa dan mengisi lembar observasi yang sesuai di lapangan.

2. Wawancara

Pada penelitian ini, peneliti menggunakan jenis wawancara terstruktur. Wawancara ini bertujuan untuk memperoleh informasi mengenai kegiatan tadarus dalam mengembangkan nilai religius siswa.. Dalam penelitian ini peneliti akan wawancara dengan Kepala Sekolah dan guru SD Negeri Pamongan 02 Guntur tentang pelaksanaan Program PKK melalui kegiatan tadarus yang telah berjalan ini dengan dengan bukti berupa catatan lapangan, rekaman video, dan material lain yang akan membantu pelaksanaan wawancara menjadi lancar.

3. Angket

Angket adalah teknik pengumpulan data melalui pernyataan secara tertulis kepada responden atau sumber data dan jawaban diberikan secara tertulis. Dalam penelitian ini angket yang digunakan tentang nilai religius siswa yang berupa pertanyaan tertutup, yaitu siswa menjawab sejumlah pernyataan berisi hal-hal yang ingin diungkap disertai alternatif jawaban. Kemudian siswa diminta untuk merespon setiap pernyataan yang sesuai dengan keadaan diri yang diketahui dengan cara memberi tanda centang $(\sqrt{ })$ pada alternatif jawaban yang tersedia.

4. Dokumentasi

Dokumen dalam penelitian ini dilakukan untuk mengumpulkan data dari dokumen berupa foto-foto mengenai pelaksanaan program PPK melalui kegiatan tadarus di SD Negeri Pamongan 02 Guntur. Kemudian peneliti akan menggabungkan dengan data hasil observasi, wawancara dan angket. 


\section{Hasil Dan Pembahasan}

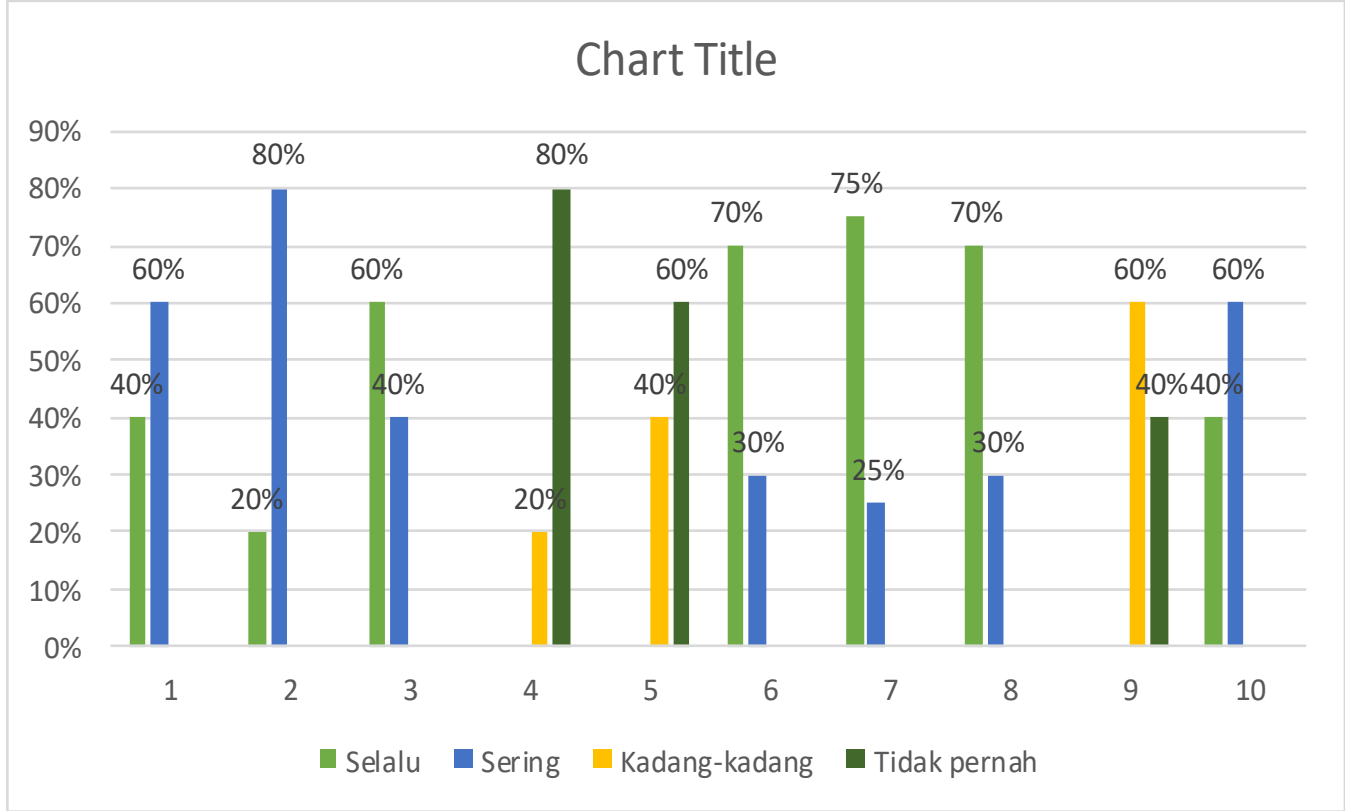

Gambar 1. Diagram Hasil Perhitungan Angket Nilai Religius Siswa Kelas III

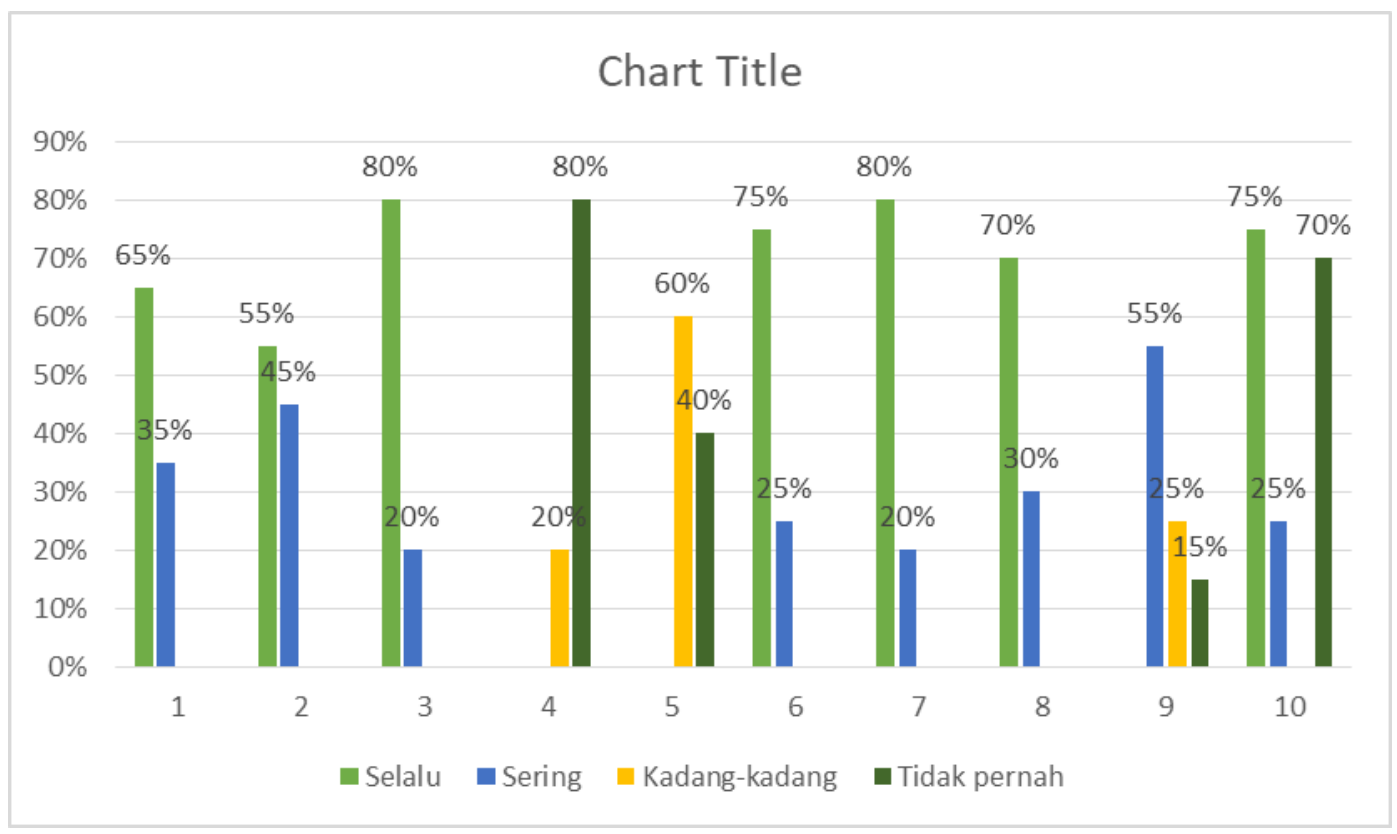

Gambar 2. Diagram Hasil Perhitungan Angket Nilai Religius Siswa Kelas IV

Berdasarkan hasil penelitian dan pembahasan pelaksanaan program PPK melalui kegiatan tadarus dalam mengembangkan nilai religius siswa di SD Negeri Pamongan 02 sudah berjalan dengan baik, hal ini dapat dilihat bahwa semua warga sekolah melaksanakan kegiatan tadarus yang dilakukan dengan cara menanamkan kebiasaan membaca Al-Qur'an selama 15 menit sebelum kegiatan belajar mengajar dimulai, sehingga dapat menumbuhkan nilai religius siswa. Nilai religius diarahkan pada sikap spiritual yang dipahami seseorang sebagai cara pandang seseorang tentang hakikat diri sendiri dengan menghargai dan menghayati ajaran agama yang dianutnya. 
Berdasarkan hasil angket dapat peneliti simpulkan bahwa nilai religius pendidikan karakter di SD Negeri Pamongan 02 Guntur menunjukkan hasil yang baik, hal ini dapat peneliti lihat dari hasil angket yang telah di isi oleh siswa kelas III dan kelas IV SD Negeri Pamongan 02 Guntur, dalam persebaran angket tersebut dapat peneliti simpulkan bahwa nilai religius sudah berjalan baik dan dapat dikatakan "Sangat Religius" karena sudah memenuhi kriteria presentassenya. Dari beberapa indikator pada angket nilai religius siswa kelas III dan kelas IV sudah menjalankannya. Pada nilai religius indikator taqwa sudah dijalankan setiap harinya, dan juga siswa sudah terbiasa dengan kebiasaan-kebiasaan yang dilakukan di sekolah, hal ini ditunjukkan dengan siwa melaksanakan sholat 5 waktu baik di sekolah maupun di rumah, siswa berbuat baik dan membantu sesama teman ketika ada teman yang sedang mengalami kesusahan, bersikap sopan terhadap guru, membantu teman ketika kesulitan mengerjakan tugas, menghargai pendapat teman ketika berdiskusi. Pada indikator senang berdoa sudah berjalan baik, hal ini dapat dilihat sebelum ulangan siswa berdoa, berdoa ketika upacara, pada saat memulai dan mengakhiri pelajaran siswa berdoa. Namun ada satu pernyataan yang belum terlihat sangat religius diantaranya yaitu hampir sebagian siswa belum mengikuti lomba keagamaan di sekolah. Nilai religius pada indikator rukun sudah dikatakan religius, hal ini dapat dilihat siswa melaksanakan hidup rukun berperilaku baik dan damai serta menghormati teman yang berbeda agama di sekolah maupun di rumah. Kondisi dari kehidupan yang rukun tersebut akan menimbulkan rasa bahu membahu, tolong menolong, dan menjauhi perselisuhan antara sesama manusia.

Dari proses pelaksanaan kegiatan keagamaan di SD Negeri Pamongan 02 ini berbasis pembiasaan, dimana siswa yang setiap harinya dibiasakan melakukan kegiatan-kegiatan keagamaan maupun kegiatan rutin tersebut sudah dilakukan oleh SD negeri Pamongan 02 sesudah berdirinya sekolah tersebut. Selain itu, peneliti juga mengamati upaya-upaya yang guru lakukan sebagai model pendidikan karakter dalam hal ini sudah sesuai dengan apa yang diharapkan dan juga dapat menjadi teladan bagi siswa kelas III dan kelas IV.

\section{Simpulan dan Saran}

Berdasarkan hasil penelitian dan pembahasan yang telah dilakukan oleh peneliti SD Negeri Pamongan 02 Guntur sudah melaksanakan program pendidikan karakter di sekolah. Upaya-upaya penanaman nilai religius yang dilakukan SD Negeri Pamongan 02 Guntur terlihat pada pelaksanaan program pendidikan karakter yang bersifat pembiasaan yang terdiri dari berdoa sebelum pembelajaran di mulai, membaca Al-Qur'an, sholat dhuhur berjamaah bersama, sholat dhuha ketika pembelajaran Agama, dan pesantren kilat yang diadakan setiap satu tahun sekali pada bulan ramadhan. Nilai religius siswa kelas III dan kelas IV SD Negeri Pamongan 02 Guntur sudah berjalan dengan baik terbukti dari hasil observasi, wawancara, dan angket. Hal itu juga dapat dilihat dari fasilitas yang menunjang pelaksanaan program pendidikan karakter melalui kegiatan tadarus, keterlibatan seluruh warga sekolah dan keberhasilan sekolah dalam penanaman nilai religius siswa.

\section{Daftar Rujukan}

Aliwar. 2016. Penguatan Model Pembelajaran Baca Tulis Quran Dan Manajemen Pengelolaan Organisasi (Tpa) . Jurnal Al-Ta'dib Vol. 9 No. 1, Januari-Juni 2016

Daryanto. 2013. Implementasi Pendidikan Karakter di Sekolah. Yogyakarta: Gava Media.

Hasbullah. 2017. Dasar-dasar Ilmu Pendidikan. Jakarta: Rajawali pers.

Kementrian Pendidikan dan Kebudayaan Republik Indonesia. 2017. Konsep dan Pedoman Penguatan Pendidikan Karakter (PPK). Jakarta: Kemendikbud.Kesuma, Dharma dkk. 
2013. Pendidikan Karakter Kajian Teori dan Praktik di Sekolah. Bandung: Remaja Rosdakarya.

Kurniawan, Syamsul. 2017. Pendidikan Karakter: Konsepsi \& Implementasinya secara Terpadu di Lingkungan Keluarga. Yogyakarta: Ar-Ruzz Media.

Ling, Misbahuddin. 2014. Dimensi Keilmuan Dalam AI-Qur'an . Jurnal at-Taqaddum, Volume 6, Nomor 2, Nopember 2014

Munirah. 2015. Sistem Pendidikan Di Indonesia: Antara Keinginan Dan Realita . Jurnal Auladuna, Vol. 2 No. 2 Desember 2015: 233-245

Mustari, Mohammad. 2013. Budaya Sekolah Pada Sekolah Menengah Pertama di Indonesia . Jurnal Kebijakan dan Pengembangan Pendidikan Volume 1, Nomor 2, Juli 2013; 185-193 ISSN: 2337-7623; EISSN: 2337-7615

Nurkholis . 2013 . Pendidikan Dalam Upaya Memajukan Teknologi . Jurnal Kependidikan, Vol. 1 No. 1 Nopember 2013

Soegeng, A.Y. 2018. Filsafat Pendidikan. Yogyakarta: Magnum Pustaka Utama.

Syarbini dan Jamhari. 2012. Kedahsyatan Membaca Al-Qur`an. Bandung: Ruang Kata Imprint Kawan Pustaka.

Sutrisno. 2016. Berbagai Pendekatan Dalam Pendidikan Nilai Dan Pendidikan Kewarganegaraan . Jurnal Dimensi Pendidikan dan Pembelajaran Vol.5 Januari 2016

Wati, Dian Chrisna dan Dikdik Arif. 2017. Penanaman Nilai-nilai Religius di Sekolah Dasar untuk Penguatan Jiwa Profetik Siswa. Jurnal. Universitas Ahmad Dahlan. Yogyakarta: 11 November 2017

Yaumi, muhammad. 2014. Pendidikan Karakter Landasan, Pilar dan Implementasi. Jakarta: PRENADAMEDIA GROUP. 